\title{
Prioritisation of Crude Oil Contaminated Sites to Inform Risk Decision Making Using Soil Quality Index
}

\author{
Douglas Reward Kokah ${ }^{1,2, *}$, Reuben Nwomandah Okparanma ${ }^{3}$, Samuel Tari Raphael $^{4}$ \\ ${ }^{1}$ School of Water, Energy and Environment, Cranfield University, Cranfield, UK \\ ${ }^{2}$ National Agency for Science and Engineering Infrastructure, Garki, Abuja, Nigeria \\ ${ }^{3}$ Department of Agricultural and Environmental Engineering, Rivers State University, Port Harcourt, Nigeria \\ ${ }^{4}$ Department of Chemical Engineering, Niger Delta University, Wilberforce Island, Nigeria
}

\section{Email address:}

r.k.douglas@cranfield.ac.uk(D. R. Kokah),rewardkdouglas@gmail.com (D. R. Kokah), okparanma.reuben@ust.edu.ng (R. N. Okparanma), raphael.samuel@ndu.edu.ng (S. T. Raphael)

${ }^{*}$ Corresponding author

\section{To cite this article:}

Douglas Reward Kokah, Reuben Nwomandah Okparanma, Samuel Tari Raphael. Prioritisation of Crude Oil Contaminated Sites to Inform Risk Decision Making Using Soil Quality Index. Engineering and Applied Sciences. Vol. 4, No. 4, 2019, pp. 79-83.

doi: $10.11648 /$ j.eas.20190404.12

Received: July 30, 2019; Accepted: August 19, 2019; Published: September 17, 2019

\begin{abstract}
Crude oil contaminated sites delineation by soil quality index (SQI) is presented. This study used SQI proposed by the Canadian Council of Ministers of the Environment (CCME) to delineate three genuinely petroleum-contaminated sites in the Niger Delta, Nigeria to prioritise sites to inform risk decision making and/or remediation. In assessing the potential impact on human health risks at the contaminated sites, soil screening levels (SL) and gas chromatography-mass spectrometry (GC-MS) reference concentrations of total petroleum hydrocarbon (TPH) fractions with higher exposure potential $\left(\mathrm{nC}_{10}-\mathrm{nC}_{16}\right.$, $\mathrm{nC}_{16}-\mathrm{nC}_{35}, \mathrm{nC}_{35}-\mathrm{nC}_{40}$ ), and risk indicator compound (benzo[a]pyrene) were used in calculating the SQI scores. The sites were assessed by scoring them on a scale spanning from 0 to 100 , where 0 indicates a very high level of human health risks and 100 indicates no action is required. The following results were obtained: (a) Site 1, SQI=36.9. This indicates high priority for remediation; (b) Site 2, SQI=49.1, which implies there is high priority for remediation and (c) Site 3 (SQI=45), which means site 3 requires high priority for remedial action. Thus, SQI method can be used to prioritse crude oil contaminated sites to enhance risk classification and decision-making and provide further insight to the contaminated land sector.
\end{abstract}

Keywords: Petroleum Hydrocarbons, Soil Quality Index, Human Health, Risk Prioritization, Remediation

\section{Introduction}

Niger Delta region is the home of Nigeria's crude oil industries, which drive the economy of the country. Consequently, environmental contamination with petroleum hydrocarbons (PHC) is widespread due to the huge number oil facilities; oil exploration and exploitation activities. These activities have attracted massive land contamination in the region [1]. Unfortunately, Nigeria currently has no developed policies that meet international standards in tackling land contamination issues irrespective of the extent of hydrocarbon contamination in the region [1]. As such, soil health; both surface and groundwater are negatively affected hence impacting drinking water quality [1-3]. Thus, many aquatic fauna and flora have been exterminated [4].

Most of the Niger Delta's population is farmers; and petroleum-contaminated soil directly affects human health via dermal contact with contaminated soils or via inhalation of the volatile fractions of PHCs. According to literature, Niger Delta is the most petroleum impacted Deltas worldwide, with devastated surface and groundwater, agricultural lands, and the local economy $[1,5]$. Thus, there is need to risk prioritise contaminated sites and inform risk decision-making. Risk assessment determines the need of an environmental cleanup, quantifying the probability and the hazard of contaminants to human health and the environment $[6,7]$.

As PHC significantly impact on human and ecosystem 
health, several national regulatory agencies usually use total petroleum hydrocarbon (TPH) concentrations to setup cleanup standards/levels for soil or groundwater [8]. Another method includes not only TPH assessment, but also polycyclic aromatic hydrocarbon (PAH); and benzene, toluene, ethylbenzene and xylene (BTEX) [9]. Soil quality standards (SQSs) are used by many national regulations to discriminate between clean, slightly contaminated, and seriously contaminated sites $[10,11]$. SQS has been defined differently by many countries, i.e. screening level (SL) in Nigeria [12], reference generic level (RGL) in Spain [13], threshold contamination concentration (TCC) in Italy [14] or threshold value (TV) in Finland [15]. Soil quality index (SQI) is a new contemporary protocol proposed for derivation of risk-based soil quality criteria for the assessment of ecological health risks at contaminated sites [16]. SQI can be used to provide a general overview of environmental quality at different petroleum contaminated sites to enable prioritising sites for further assessment or remediation [16]. The assessment of oil-contaminated soils using SQI requires comparison between screening level (SL) and measured concentrations in calculation. The SQI provides quantitative values ranging from 0 to 100 , where 0 indicates a very high level of ecological health risks and 100 indicates no unacceptable ecological concern.

SQI has been applied in various areas of research that interfere with soil functions. Some of these areas include agriculture, mining, and petroleum industry. In the agricultural sector, SQI has been used to assess crop productivity in a semi-arid region [17], and the evaluation of the impact of rice production methods that utilise irrigation with groundwater on soil having high content of expansive clay [18]. Some soil chemical properties used by these researchers for the calculation of SQI include electrical conductivity (EC), organic matter (OM), exchangeable sodium content, cation exchange capacity, total phosphorus among others. SQI has been applied to assess trends in forest soil quality and establish baseline levels for different soil and forest types [19]. The authors used soil variables including total organic carbon, total nitrogen, soil organic matter, $\mathrm{pH}$ bulk density among others. In the petroleum industry, SQI has been applied in the environmental impact assessment of a gas development project in Niger Delta, Nigeria [20]. In the calculation of SQI, TPH and some soil properties including percent sand, $\mathrm{pH}$, total organic carbon, and electrical conductivity [19]. In a recent study, SQI was applied to assess the effectiveness of enhanced natural attenuation of contaminated site (s) in the Niger Delta, Nigeria [21].

To date, there is no study in the independent literature using SQI as quantitative tool in assessing and rating of genuinely petroleum contaminated sites in Nigeria. Consequently, the objective of the study was to analyse soils collected from petroleum contaminated sites in the Niger Delta region of Nigeria to enable prioritising sites for further assessment or remediation. A risk indicator compound [benzo[a]pyrene $(\mathrm{BaP})]$ in crude oil and $\mathrm{TPH}$ fractions $\left(\mathrm{nC}_{10^{-}}\right.$ $\mathrm{nC}_{16}, \mathrm{nC}_{16}-\mathrm{nC}_{35}, \mathrm{nC}_{35}-\mathrm{nC}_{40}$ ) were included to improve soil quality assessment as proposed by [16] at crude oil contaminated sites. For this purpose, gas chromatographymass spectrometry (GC-MS) measured concentrations of the mentioned indicator compound and the TPH fractions in contaminated soil were compared with their SLs.

\section{Materials and Methods}

\subsection{Study Area and Soil Sampling}

The soil samples were collected from three oil spill sites (Site 1:6.4527 $7^{\circ}$ E, $5.1542^{\circ} \mathrm{N}$; Site 2: $6.4511^{\circ} \mathrm{E}, 5.1357^{\circ} \mathrm{N}$; Site 3: $6.1224^{\circ} \mathrm{E}, 4.9314^{\circ} \mathrm{N}$ ) in the Niger Delta region of Nigeria (Figure 1). For more details on the studied area and samples used (e.g., sampling location, method for sample collection, sampling depth, mass of samples, and sample preservation) readers are kindly referred to the study [22].

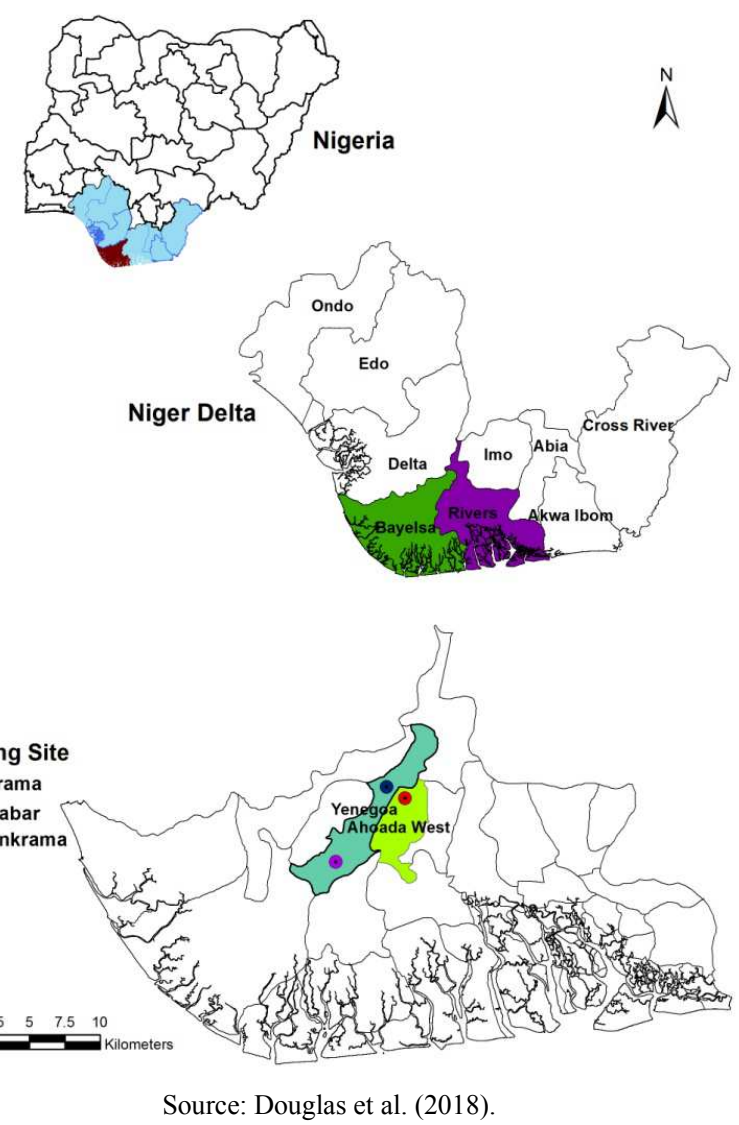

Figure 1. Soil sampling locations for the three sites.

\subsection{Gas Chromatography and Hydrocarbons Quantification}

The petroleum hydrocarbons extraction method and GCMS analysis used in this study followed the procedure described by [21] with some modifications. Briefly, $5 \mathrm{~g}$ of soil sample was mixed with $20 \mathrm{ml}$ of dichloromethane (DCM): hexane (Hex) solution $(1: 1, \mathrm{v} / \mathrm{v})$, shaken for $16 \mathrm{~h}$ at 150 oscillations per min, and finally sonicated for $30 \mathrm{~min}$ at $20^{\circ} \mathrm{C}$. The validation methodology was set against a robust and validated GC-MS method previously reported [21]. More 
details about the chemical analysis for hydrocarbon concentrations can be found in the study [22].

\subsection{Calculation of $S Q I$}

In Nigeria, the $\mathrm{SL}$ for $\mathrm{TPH}$ is $50 \mathrm{mg} \mathrm{kg}^{-1}$ whereas there is no SL for PAH at the moment. Thus, the SL for TPH was used for PAH while a SL of $0.24 \mathrm{mg} \mathrm{kg}^{-1}$ was adopted for benzo[a]pyrene as previously proposed by the researcher [23]. To assess the human health risks at the studied petroleum impacted sites using SQI, three factors, namely scope $\left(\mathrm{F}_{1}\right)$, frequency $\left(\mathrm{F}_{2}\right)$, and amplitude $\left(\mathrm{F}_{3}\right)$ were applied as proposed by the research [16]. $F_{1}$ corresponded to the percentage of contaminants that did not meet their respective soil quality guidelines (SQG) and was calculated using equation 1 [16].

$$
\mathrm{F} 1=\frac{\text { Number of failed contaminants }}{\text { Total number of contaminants }} \times 100
$$

$\mathrm{F}_{2}$ corresponded to the percentage of contaminants that did not meet their respective SQG and was calculated using equation 2 [16].

$$
\mathrm{F} 2=\frac{\text { Number of failed tests }}{\text { Total number of tests }} \times 100
$$

$\mathrm{F}_{3}$ means the amount by which the contaminants did not meet their respective SQG and was calculated using equation 3 [16].

$$
\mathrm{F} 3=\frac{\mathrm{ASE}}{0.01(A S E)+0.01}
$$

where, E represents excursion, which refers to the concentration of the contaminants that is greater than the SQG and was calculated using equation (4); if the test value must not exceed the SQG [16].

$$
\mathrm{E}=\frac{\text { Failed Test Value }_{\mathrm{i}}}{\text { Guideline }_{\mathrm{i}}}-1
$$

The ASE corresponds to the average sum of excursions, which in turn refers to the average amount by which individual tests are not in compliance. This was computed using equation 5 [16]. The SQI was calculated using equation $6[16]$.

$$
\begin{aligned}
A S E & =\frac{\sum_{i=1}^{n} \text { Excursion }_{\mathrm{i}}}{\text { Number of failed test }} \\
\mathrm{SQI} & =100-\frac{\sqrt{\mathrm{F}_{1}^{2}+\mathrm{F}_{2}^{2}+\mathrm{F}_{3}^{2}}}{1.732}
\end{aligned}
$$

The divisor, 1.732 normalises the final SQI values to a range between 0 and 100; where, 0-30 implies very high, 3050 implies high, 50-70 implies medium, 70-90 implies low, and 90-100 implies very low ecological health risk due to contamination [16].

\section{Results and Discussion}

\subsection{TPH and BaP Concentrations at Study Sites}

Table 1 shows the statistical summary of the TPH fractions concentrations and $\mathrm{BaP}$ concentrations in the three study sites. In site $1, \mathrm{TPH}$ concentrations spanned from 0.00 to $447.18 \mathrm{mg} \mathrm{kg}^{-1}$ while BaP from 0.00 to $0.95 \mathrm{mg} \mathrm{kg}^{-1}$. TPH fraction spanned from 0.35 to $249.81 \mathrm{mg} \mathrm{kg}^{-1} 1$ whereas BaP from 0.02 to $0.50 \mathrm{mg} \mathrm{kg-1}$ in site 2 . In site $3, \mathrm{TPH}$ concentrations ranged between 0.00 and $447.18 \mathrm{mg} \mathrm{kg}^{-1}$ while $\mathrm{BaP}$ between 0.00 and $0.95 \mathrm{mg} \mathrm{kg}^{-1}$. Overall, site 1 is appears to be the most contaminated followed by site 3 and then site 2 . The relatively low concentrations of TPH F1: $\mathrm{nC}_{10}$ and $\mathrm{TPH} F 2: \mathrm{nC}_{10}-\mathrm{nC}_{16}$ across the three sites may be

\begin{tabular}{|c|c|c|c|c|c|c|c|c|c|c|c|c|}
\hline \multirow{2}{*}{$\begin{array}{l}\text { Hydrocarbon } \\
\text { fractions (mg.kg) }\end{array}$} & \multicolumn{4}{|c|}{ Site 1} & \multicolumn{4}{|c|}{ Site 2} & \multicolumn{4}{|c|}{ Site 3} \\
\hline & $\mathbf{N}$ & Median & Min & $\operatorname{Max}$ & $\mathbf{N}$ & Median & Min & $\operatorname{Max}$ & $\mathbf{N}$ & Median & Min & $\operatorname{Max}$ \\
\hline TPH F1:nC10 & 31 & 1.50 & 0.00 & 6.54 & 21 & 2.34 & 0.35 & 6.02 & 33 & 4.19 & 0.10 & 36.01 \\
\hline TPH F2:nC10-nC16 & 31 & 27.42 & 6.00 & 105.32 & 21 & 28.36 & 10.22 & 83.09 & 33 & 39.36 & 2.45 & 174.58 \\
\hline TPH F3:nC16-nC35 & 31 & 128.50 & 33.79 & 447.18 & 21 & 119.48 & 36.15 & 249.81 & 33 & 99.84 & 9.27 & 363.20 \\
\hline TPH F4:nC35-nC40 & 31 & 2.18 & 0.34 & 172.64 & 21 & 2.29 & 0.49 & 7.85 & 33 & 4.97 & 0.83 & 20.93 \\
\hline $\mathrm{BaP}$ & 31 & 0.05 & 0.00 & 0.95 & 21 & 0.07 & 0.02 & 0.50 & 33 & 0.45 & 0.02 & 1.94 \\
\hline
\end{tabular}
attributed to their higher volatility behaviour compared to the other fractions. Also, soils were observed to be less contaminated with $\mathrm{BaP}$ (risk indicator compound).

Table 1. Hydrocarbon concentrations and statistics across the study sites. Min, Max, and N represents minimum, maximum concentration, and number of samples, respectively. F1, F2, F3, and F4 represent total petroleum hydrocarbon (TPH) fractions.

\subsection{Soil Contaminants Information for The Three Study Sites}

The hydrocarbon analytical data for the computation of SQI is shown in Table 2. In site 1, the number of failed contaminants, total number of contaminants, number of failed tests, and total number of tests were 4, 5, 40, and 155, respectively. Similarly, 3, 5, 23, and 105 represents the number of failed contaminants, total number of contaminants, number of failed tests, and total number of tests, respectively in site 2. The number of failed contaminants, total number of contaminants, number of failed tests, and total number of tests in site 3 were 3, 5, 62, and 165 , respectively. Site 3 had more number of failed tests (62) compared to either site 2 (23) or site 1 (40). 
Table 2. Summary of soil contaminants' information in the study sites. This was obtained from the SQI computation.

\begin{tabular}{lllll}
\hline Site & NFC & TNC & NFT & TNT \\
\hline IK & 4 & 5 & 40 & 155 \\
KA & 3 & 5 & 23 & 105 \\
JK & 3 & 5 & 62 & 165 \\
\hline
\end{tabular}

$\mathrm{IK}=\mathrm{Ikarama}$ sampling site, $\mathrm{KA}=\mathrm{Kalabar}$ sampling site, JK=Joinkrama sampling site, $\mathrm{NFC}=$ number of failed contaminants, $\mathrm{TNC}=$ total number of contaminants, NFT $=$ number of failed tests, and TNT $=$ total number of tests.

\subsection{SQI for the Three Study Sites}

Summary of SQI calculation and conclusions of the study sites are presented in Table 3. Results show that the sites were contaminated with TPH and BaP spanning between 49.1 and 36.9, indicating high level of contamination. The level of contamination at site 1 , site 2 , and site 3 are all rated high. Consequently, all study sites require adequate remediation to meet soil quality guidelines set by [12]

Table 3. Summary of soil quality index (SQI) calculation and conclusions of the study sites.

\begin{tabular}{|c|c|c|c|c|c|c|c|c|c|}
\hline \multirow{2}{*}{ Site name } & \multicolumn{6}{|c|}{ Calculation } & \multicolumn{3}{|l|}{ Conclusions } \\
\hline & F1 & F2 & Sum (E) & ASE & F3 & SQI & Level of concern & Contaminant & Management option \\
\hline IK & 80.00 & 25.81 & 89.02 & 2.23 & 69.88 & 36.90 & High & $\mathrm{TPH}$ and $\mathrm{BaP}$ & High priority for remediation \\
\hline KA & 60.00 & 21.9 & 35.79 & 1.56 & 60.88 & 49.10 & High & $\mathrm{TPH}$ and $\mathrm{BaP}$ & High priority for remediation \\
\hline JK & 60.00 & 37.58 & 108.55 & 1.75 & 63.65 & 45.00 & High & $\mathrm{TPH}$ and $\mathrm{BaP}$ & High priority for remediation \\
\hline
\end{tabular}

$\mathrm{F} 1$ is the same as in equation 1; F2 is the same as in equation 2; F3 is the same as in equation 3; E is the same as in equation 4; ASE means average sum of excursions; TPH; total petroleum hydrocarbon; and BaP; benzo[a]pyrene.

\section{Conclusions}

This study presents the usefulness of the SQI for screening petroleum-contaminated sites in the Niger Delta region of Nigeria which has not been previously carried out. SQI was used as a qualitative tool for the assessment and ranking of crude oil contaminated sites to inform risk decision-making in three selected oil spill sites located in the region. The following conclusions were drawn based on the results:

1. There are high ecological and human health risks at the three study sites. This suggests high priority for remediation.

2. SQI provides a clear and logical framework for contaminated site prioritisation and risk assessment decision-making at petroleum-release sites in the Niger Delta region of Nigeria.

Further research is imperative to cover most of oil spill sites in the Niger Delta region to help diagnose contaminated land sites to support risk classification and remediation.

\section{Acknowledgements}

We acknowledged the Petroleum Technology Development Fund (PTDF) of Nigeria with Grand No: PTDF/OSS/PHD/711/14, whose financial support in the form of doctoral studentship has lead to this publication.

\section{References}

[1] UNEP (United Nations Environment Program) (2002). Environmental Assessment of Ogoniland. UNEP, Switzerland.

[2] Nganje, T. N., Hursthouse, A. S., Edet, A., Stirling, D., and Adamu, C. I. (2015). Hydrochemistry of surface and groundwater in the shale bedrock, Cross River Basin and Niger Delta region, Nigeria. Appl. Water Sci. 7, 961-985.

[3] Davies, O., and Abolude, D. (2016). Polycyclic aromatic hydrocarbons (pahs) of surface water from Oburun Lake,
Niger Delta, Nigeria. Appl. Sci. Res. 13, 20-24.

[4] Luiselli, L., Amori, G., Akani, G. C., and Eniang, E. A. (2015). Ecological diversity, community structure and conservation of Niger Delta mammals. Biodivers. Conserv. 24: 2809-2830.

[5] Zabbey, N., and Uyi, H. (2014). Community responsesof intertidal soft-bottom macrozoobenthos to oil pollution in a tropical mangrove ecosystem, Niger Delta, Nigeria. Mar. Pollut. Bull. 82: 167-174.

[6] Brewer, R., Nagashima, J., Kelly, M., Heskett, M., and Rigby, M. (2013). Risk-based evaluation of total petroleum hydrocarbons in vapour intrusion studies. Int. J. Environ. Res. Public Health, 10 (6), 2441-2467.

[7] Rebelo, A., Ferra, I., Goncalves, I., and Marques, A. M. (2014). Risk assessment model for water resources: Releases of dangerous and hazardous substances. J. Environ. Manage., $140,51-59$.

[8] Park, I. S., and Park, J. W. (2010). A novel total petroleum hydrocarbon strategy for human health risk assessment for petroleum-contaminated site management. J. Hazardous Mater, 179 (1-3), 1128-1135.

[9] ISO (2012). Soil Quality-Assessment of impact from soil contamination with petroleum hydrocarbons. ISO 11504:2012. International Organization for Standardisation, Geneva, Switzerland.

[10] Swartjes, F. A., Rutgers, M., Lijzen, J. P. A., Janssen, P. J. C. M., Otte, P. F., Wintersen, A., Brand, E., and Posthuma, L. (2012). State of the art of contaminated site management in the Netherlands: Policy framework and risk assessment tools. Sci. Total Environ. 427-428, 1-10.

[11] VROM (Dutch Ministry of Housing, Spatial Planning and the Environment), (2012). Site Remediation Circular 2009. Staatscourant 3 April 2012, Nr 6563. Ministry of Housing, Spatial Planning and the Environment, The Hague.

[12] DPR (Department of Petroleum Resources) (2002). Environmental Guidelines and Standards for the Petroleum Industry in Nigeria (EGASPIN). Ministry of Petroleum and Natural Resources, Abuja, Nigeria, P. 314. 
[13] Presidency Ministry (Spain) (2005). Royal Decree 9/2005 of 14 January Which Establishes a List of Potentially Soil Contaminating Activities and Criteria and Standards for Declaring that Site Are Contaminated. Official State Bulletin 15/2005. Presidency Ministry, Madrid, Spain (in Spanish) pp. 1833-1843.

[14] Italian Ministry of Environment (2006). Legislative Decree $3^{\text {rd }}$ April 2006, no. 152. Ambient Normative published in the Official Gazette no 88, 14 ${ }^{\text {th }}$ April 2006-suppl. Ord. no. 96. Italian Ministry of Environment, Rome, Italy (in Italian).

[15] Finnish Ministry of the Environment (2007). Government Decree on the assessment of soil contamination and Remediation Needs, 214/2007. Finnish Ministry of the Environment, Helsinki, Finland.

[16] CCME (Canadian Council of Ministers of the Environment) (2007). CCME soil quality index 1.10: technical report. In: Canadian Soil Quality Guidelines for the protection of the Environment and Human Health. Canadian Council of Ministers of the Environment, Winnipeg.

[17] Vasu, D., Singh, S. K., Ray, S. K., Duraisami, V. P., Tiwary, P., Chandra, P., Nimkar, A. M., and Anantwar, S. G. (2016). Soil quality index as a tool to evaluate crop productivity in semiarid Deccan plateau, India. Geoderma 282, 70-79.

[18] Sione, S. M. J., Wilson, M. G., Lado, M., and Gonzalez, A. P. (2017). Evaluation of soil degradation produced by rice crop system in vertisol, using soil quality index. CATENA 150, 79-86.
[19] Amacher, M. C., O’Neill, K. P., and Perry, C. H. (2007). Soil Vital Signs: A New Soil Quality Index (SQI) for Assessing Forest Soil Health. United States Department of Agriculture. Forest Service Research Paper RMRS-RP-65WWW.

[20] SPDC (Shell Petroleum Development Company) of Nigeria (2005). Environmental Impact Assessment (EIA) of the Assa North-Ohaji South Gas Development Project (The Facilities) at Ohaji/Egbema LGA, Imo State.

[21] Risdon, G. C., Pollard, S. J. T., Brassington, K. J., McEwan, J. N., Paton, G. I., Semple, K. T., and Coulon, F. (2008). Development of an analytical procedure for weathered hydrocarbon contaminated soils within a UK risk-based framework. Anal. Chem. 80, 7090-7096.

[22] Douglas, R. K., Nawar, S., Alamar, M. C., Mouazen, A. M., Coulon, F., 2018. Rapid prediction of total petroleum hydrocarbons concentration in contaminated soil using visNIR spectroscopy and regression techniques. Sci. Total Environ. 616-617, 147-155.

[23] Okparanma, R. N., Azuazu, I., and Ayotamuno, J. M. (2017). Assessment of the effectiveness of onsite exsitu remediation by enhanced natural attenuation in the Niger Delta region, Nigeria. J. Environ. Manage, 204, 291-299. 